\title{
Does the Possession of a Kadazandusun Traditional Costume and the Capability to Play a Traditional Musical Instrument Differentiate an Individual's Identity Orientation?
}

\author{
By Getrude Cosmas ${ }^{*}$, Agnis Sombuling ${ }^{\dagger}$ Ben Anderson AK \\ Melai $^{+} \&$ Andrew Poninting ${ }^{+}$
}

\begin{abstract}
The aim of this study was to examine the differences between Kadazandusun participants who possessed and who do not possess a traditional Kadazandusun costume in regard to the four types of identity orientation (i.e. personal, relational, social \& collective). These differences were also assessed between participants who were and were not able to play a traditional musical instrument. A total of 242 Kadazandusun participants were enrolled, and the study used a survey questionnaire with two sections. Section A included questions about the demographic profile (age, gender, ethnicity, possession of a traditional costume, ability to play a traditional musical instrument, and education level), while Section B measured the four types of identity orientation (i.e. personal, relational, social \& collective). We hypothesized that participants who possessed a Kadazandusun traditional costume and those who could play a traditional musical instrument had higher relational and collective identity orientation. The study revealed that those who possessed a Kadazandusun traditional costume had higher relational, social, and collective selfidentity compared to those who did not own a costume. Further, those who could play a traditional musical instrument only showed higher on social identity orientation than those who could not play any traditional musical instrument. These findings showed that people's identity orientation may differ based such cultural elements (e.g., possession of a Kadazandusun traditional costume and ability to play a traditional musical instrument). These findings may provide an understanding of the importance of cultural elements in identity orientation, particularly for the indigenous group of Kadazandusuns in Sabah, Malaysia.
\end{abstract}

Keywords: Kadazandusun, personal, relational, social and collective self-identity.

\section{Introduction}

Self and identity researchers have a long-standing belief that the self is both the product of situations and the shaper of behaviour in situations (Oyserman et al. 2012). Various factors, such as gender, culture, family, media and religion can influence a person's identity orientation. For indigenous groups, culture might be one of the factors that contribute to their identity orientation. Culture refers to the

\footnotetext{
${ }^{*}$ Senior Lecturer, University of Malaysia Sabah, Malaysia.

${ }^{\dagger}$ Senior Lecturer, University of Malaysia Sabah, Malaysia.

${ }^{\ddagger}$ Lecturer, University of Malaysia Sabah, Malaysia.

${ }^{+}$Senior Lecturer, University of Malaysia Sabah, Malaysia.
} 
language, beliefs, values and norms, customs, dress, diet, roles, knowledge and skills as well as other aspects that people learn and inculcate as the way of life in any society (Anthony 1996). Cultural factors such as traditional costume, music, and custom may reflect cultural identity among an indigenous group. According to Matsumoto (2000), culture plays a major role in shaping our sense of self and identity. There are various types of identity or self-concept (i.e. personal, social, relational, \& collective). Personal identity is defined as a person's traits, characteristics and attributes, goals and values as well as ways of being. Social identities include a person's roles; interpersonal relationships and group memberships; as well as the traits, characteristics, attributes, goals, and values congruent with these roles, relationships, and memberships (Oyserman et al. 2012). Social identity is also defined as the awareness of being a member of a group, one's feelings about group membership, and the knowledge of the rank or status of one's own group compared to those of other groups (Tajfel 1981). The relational self, on the other hand, highlights one's interpersonal aspect. It consists of attributes that are shared with close others (e.g. partners, friends, \& family members) and defines the roles within the relationship. This self-representation reflects valued interpersonal attachments. Finally, the collective self highlights the unique aspects of one's group that are shared with the group members, differentiating them from non-members (Sedikides et al. 2011).

Traditional costume and music are among the most common aspects of cultural expression used to identify a particular ethnic group. For example, the Kadazandusuns express their identity through their ancestral cultural practices of wearing the traditional costume and playing a traditional music instrument. The Kadazandusun traditional costume can be easily differentiated from those of other ethnic groups because of its characteristic black velvet fabric and unique colourful embroidery (Doksil 2016). The Kadazandusun traditional costumes for female is worn together with "himpogot" belts made from silver coins, and the three sets of hip belts called "tangkung". Males wear a headgear called "sigar" and females wear hats or scarves. Many scholars believed the black colour symbolises power which can protect the wearer against evil spirits, while others believe the colour suited the lifestyle of the ethnic people, whose forefathers had lived in a state of nature (Mohd Said 2018).

Kadazandusuns dressed in a traditional costume show the ethnicity of Kadazandusun culture. Traditional attires, like Sinuangga of the Kadazan from Penampang, the Sinipak of Tindal Kota Belud, the Siya of Kadazan Papar, the Kinaling of Kimaragang Kota Belud, and the Sukolob of the Rungus women in Kudat, Pitas and Banggi are often worn during special occasions, such as the Kaamatan festival (Doksil 2016), weddings, cultural and religious ceremonies. Kadazandusun traditional attires from other districts are the Minglap (top) and Tapik (skirt) of the Dusun Subpan from Lahad Datu, the Kuizou of Dusun Beaufort (Doksil 2015) and the sira lambung of the Dusun Tatana, Kuala Penyu. Apart from traditional costume, the Kadazandusun self-identity is also expressed through their traditional music instruments such as the kulintangan, gandang, gong, bungkau, tongkibong and tongkungon (Chong 2015). The older generations are striving to preserve their cultural traditions, and certain ancient musical 
elements are still retained in their modern music and accepted by the young musicians.

Based on the preceding arguments, we were interested in examining the differences in the four identity orientations types (personal, relational, social, \& collective) (personal, relational, social, \& collective) between Kadazandusun participants who did and did not possess their cultural costume on the four types of identity orientation. In addition, we also examine the differences in the four identity orientation types (personal, relational, social, \& collective) between the participants who had the ability to play a traditional musical instrument and those who did not. We focused on the Kadazandusun indigenous ethnic community of Sabah, Malaysia because it has a rich cultural heritage comprised of traditional costumes, traditional music, customs, and language. The Kadazandusun community, which includes 40 sub-ethnic groups, most frequently resides on the western coast and interior regions of Sabah such as Kota Marudu, Kota Belud, Tuaran, Kota Kinabalu, Tanjung Aru, Putatan, Papar, Beaufort, Kuala Penyu, Keningau, Tambunan, Ranau, Kinabatangan, Sipitang, Tawau, and Lahad Datu. The Kadazandusun constitute the most numerous groups or suku from different districts such as Tangaah (Penampang \& Papar), Tatana (Kuala Penyu), Idaan or Tindal (Kota Belud), Kimaragang (Tandek, Kota Marudu), Liwan (Ranau \& Tambunan), Lotud (Tuaran), Bonggi (In Banggi Island, Kudat), Tidong (Tawau) and Bagahak, Dumpas as well as Tombinuo and Buludupis (Kinabatangan) (Luping 2009). We hope the study's findings will contribute to the Kadazandusun cultural literature, providing knowledge to the Kadazandusun community regarding the importance of two cultural elements (i.e. traditional costume and traditional music) to the Kadazandusuns' identity orientation.

\section{Methodology}

\section{Participants}

A total of 242 Kadazandusuns from various districts participated in this study. Although they were from various groups of Kadazandusuns such as Dusun Ranau, Tambunan, Keningau, Tamparuli, Kota Belud, Kota Marudu, Penampang, Papar, Membakut, and Kuala Penyu and use different dialects, they were all from the Dusunic family as stated by Dayu (2014).

\section{Instrument}

Survey questionnaires were distributed to the participants for assessing their self-concept. The questionnaire had two sections; Section A included questions about demographic characteristics, and Section B contained questions about the four types of identity orientation.

\section{Section A: Demographics}


There were 18 items in this section, including age, sex, ethnicity, educational level, location, possession (or not) of a Kadazandusun traditional costume, and ability (or inability) to play a traditional Kadazandusun musical instrument.

Section B: Aspects of Identity Questionnaire (AIQ-IV) (Cheek and Briggs 2013)

The self-concept scale consisted of 45 items to measure the four types of identity orientation (i.e. personal, relational, social, and collective). The responses were obtained using a 5-point scale with 1 indicating "not important to my sense of who I am" and 5 representing" extremely important to my sense of who I am". A higher overall score indicated a participant's self-concept.

\section{Results}

The reliability scale scores for self-concept and each type of self-concept were acceptable, ranging from .64 - .82 (see Table 1).

Table 1. Reliability Values Scale and Each Subscale of Self-concept $(N=242)$

\begin{tabular}{|l|l|c|c|}
\hline No & Scale and subscales for self-concept & Number of items & Reliability values \\
\hline 1. & Personal identity orientation & 10 & .67 \\
\hline 2. & Relational identity orientation & 10 & .87 \\
\hline 3. & Social identity orientation & 7 & .64 \\
\hline 4. & Collective Identity orientation & 8 & .79 \\
\hline
\end{tabular}

\section{Kadazandusun Participants' Demographic Profile}

Table 2 shows the demographic profiles of Kadazandusun participants. The majority of the participants were females: 160 females $(66.10 \%)$ and 82 males (33.90\%). The mean age of participants was 19.32, $(S D=3.49)$.

The Kadazandusun participants belonged to different Kadazandusun groups and districts such as Tangaah (Penampang \& Papar), Tatana (Kuala Penyu), Idaan or Tindal (Kota Belud), Lotud (Tuaran and Tamparuli), Kimaragang (Tandek, Kota Marudu), Liwan (Ranau \& Tambunan). The majority of participants were Christian at $216(89.30 \%)$, followed by Muslim at 23 (9.50\%) and Buddhist, 1 $(.40 \%)$. Most of the participants knew their traditional music at $219(90.50 \%)$. The remaining $22(9.10 \%)$ participants did not know their traditional music. In terms of traditional costume, Kadazandusun participants wear their traditional costume during special occasions such as Harvest Festival, wedding receptions, formal events (e.g. graduation day), religious activities and traditional dance competition. 
Table 2. Demographic Profile of Kadazandusun Participants ( $N=242)$

\begin{tabular}{|l|c|c|}
\hline Variables & N & Percentage \\
\hline Gender & 82 & 33.90 \\
Male & 160 & 66.10 \\
Female & & \\
\hline Religion & 216 & 89.30 \\
Christian & 23 & 9.50 \\
Muslim & 1 & .40 \\
Buddhist & 2 & .80 \\
Missing values & & \\
\hline Do you possess your traditional kadazandusun costume? & 147 & 60.70 \\
Yes & 95 & 39.30 \\
No & & \\
\hline Have you ever worn the Kadazandusun costume? & 211 & 87.20 \\
Yes & 29 & 12.00 \\
No & 2 & .80 \\
Missing values & & \\
\hline How frequently do you wear the Kadazandusun costume? & 179 & 74.00 \\
Rarely & 26 & 10.70 \\
Seldom & 7 & 2.90 \\
Always & 22 & 9.10 \\
Never wear & 8 & 3.30 \\
Missing values & & \\
\hline When did you wear the Kadazandusun costume? & 62 & 25.60 \\
Harvest Festival & 52 & 21.50 \\
Wedding reception & 43 & 17.80 \\
Formal event & 37 & 15.30 \\
Religious activities & 2 & .80 \\
Traditional dance competition & 1 & .40 \\
Family photo sessions & 25 & 10.30 \\
All activities & 3 & 7.00 \\
Never wear & 17 & 1.20 \\
Missing values & 219 & 90.50 \\
\hline Do you know your traditional music? & 22 & 9.10 \\
Yes & & \\
No & & \\
& & \\
\hline
\end{tabular}

A Comparison between Participants who did and did not Possess Traditional Costumes in regard to the four types of identity orientation

The study showed that there were significant differences between Kadazandusun participants who did and did not possess a Kadazandusun traditional costume with respect to three types of identity orientations, that is, relational identity, social identity, and collective identity. Participants who possessed a traditional costume scored higher mean scores for each of the three identities. However, for personal identity, there was no significant difference between the two groups (see Table 3). 
Table 3. Analyses of the Comparison between Participants who did and did not Possess Traditional Costumes with Respect to the Four Components of SelfConcept

\begin{tabular}{|l|c|c|c|c|c|}
\hline Variables & N & Mean (SD) & t values & df & Sig. \\
\hline Personal Identity & & $40.23(5.48)$ & & & \\
$\begin{array}{l}\text { Possess } \\
\text { Do not possess }\end{array}$ & 94 & $39.95(9.22)$ & 1.21 & 233 & .23 \\
\hline $\begin{array}{l}\text { Relational Identity } \\
\text { Possess }\end{array}$ & 142 & $39.46(6.42)$ & 3.22 & 232 & .00 \\
Do not possess & 92 & $36.43(7.39)$ & & & \\
\hline Social identity & 146 & $25.02(5.06)$ & 2.63 & 237 & .00 \\
$\begin{array}{l}\text { Possess } \\
\text { Do not possess }\end{array}$ & 93 & $23.20(5.29)$ & & & \\
\hline $\begin{array}{l}\text { Collective Identity } \\
\text { Possess }\end{array}$ & 138 & $32.65(4.14)$ & 2.96 & 227 & .00 \\
Do not possess & 91 & $30.45(6.24)$ & & & \\
\hline
\end{tabular}

A Comparison between Participants with and Without the Ability to Play a Traditional Music in Regard to the Four Components of Self-Concept

In terms of the ability to play an instrument, our study found a significant difference with respect to the social identity orientation between participants who were able and unable to play a traditional Kadazandusun musical instruments (i.e., Kulintangan, Tagong, Kalibadon, sumpoton, kalibadon (second gong) or gagandang). There were no differences found for their relational identity, personal identity and collective identity orientation between participants who were able and unable to play a Kadazandusun traditional musical instrument (see Table 4).

Table 4. Analysis of the Comparison between Participants with and without the Ability to Play a Traditional Music in Terms of the Four Components of Self-Concept

\begin{tabular}{|l|c|c|c|c|c|}
\hline Variables & N & Mean (SD) & t values & df & Sig. \\
\hline $\begin{array}{l}\text { Personal Identity } \\
\text { With ability } \\
\text { Without ability }\end{array}$ & 104 & $\begin{array}{l}40.52(8.69) \\
38.18(5.73)\end{array}$ & 1.35 & 230 & .18 \\
\hline $\begin{array}{l}\text { Relational Identity } \\
\text { With ability }\end{array}$ & 106 & $38.50(7.16)$ & .85 & 229 & .64 \\
Without ability & 125 & $38.08(6.79)$ & & & \\
\hline $\begin{array}{l}\text { Social identity } \\
\text { With ability }\end{array}$ & 109 & $25.29(5.72)$ & 3.04 & 234 & .00 \\
Without ability & 127 & $23.49(4.65)$ & & & \\
\hline $\begin{array}{l}\text { Collective Identity } \\
\text { With ability } \\
\text { Without ability }\end{array}$ & 104 & $32.38(5.00)$ & 2.07 & 225 & .10 \\
\hline
\end{tabular}




\section{Discussion}

\section{Traditional Costume and Identity Orientation}

Our study showed that the participants who possessed a traditional Kadazandusun costume tended to have higher relational, social, and collective identity orientation. We believe that these three types of identity orientation place emphasise a sense of feelings and relationships with their in-group. Social constructionist theories suggest that people have many identities, each created through interactions with other people rather than a single, core identity (Hargreaves et al. 2002). With respect to the correlation between the possession of a traditional costume and identity orientation, we believe that Kadazandusuns who own their ethnic traditional costume might feel emotionally closer to their ethnic origin or community. When people wear their traditional costume, they display their collective identity. People who wear their traditional costume with accessories tend to feel connected with their ethnicity. Poletta and Jasper (2001) stated that collective identity is defined as an individual's cognitive, moral, and emotional connection with a broader community. A traditional costume is commonly used to identify people of particular cultural groups and serves to distinguish the wearer's social position (Pohl 1998).

In the Kadazandusun community, most of the traditional costumes worn by Kadazan men and women are predominantly dark or black in color. Silver coin belts, rattan or beaded waist bands, beaded necklaces, and other silver ornaments and accessories are worn with these costumes. For the headgear, the women wear hats or scarves, while the men wear a head cloth called sigar or kain dasar, a piece of cloth draped, folded, and tied according to district's style and pattern. The Kadazandusun dress codes vary from one district to another (Kadazan 2009). Wearing traditional costume reflects the Kadazandusun community, which may bring a sense of pride of the Kadazandusuns' roots and cultural heritage. Wearing a traditional costume and its accessories tend to make group members feel connected with their ethnicity (Poletta and Jasper 2001). This might be one of the reasons why the Kadazandusun participants who possessed a traditional Kadazandusun costume tended to have higher relational, social, and collective identity orientation.

For most cultures, ethnic clothing is a symbol of identity and a basic means of communication commonality (Roach-Higgins and Eicher 1992). A traditional costume has long been recognised as a marker of ethnic identity (Lee 2015). Ethnic costumes can strengthen the interrelationship among members of the same ethnic group. For example, the Korean traditional dress called hanbok, an abbreviation of the term haisuk boksik (Korean attire) remains a strong indicator of national identity and values in that culture (Carrause 2012). Social identity defines individuals in relation to the social groups with which they identify and to which they belong, and it defines the differences with other social groups and individuals. Each community expresses its ethnic identity through such traditional costumes. For instance, the Japanese believe wearing kimonos can connect them with their ancestral cultural identity. Wearing a kimono is often associated with 
"Japaneseness" and is regarded as a conscious decision to return to one's true Japanese identity (Assman 2008). Pakistani Muslim girls who wear the salwar kameez (punjab suit) in the public space of their community feel a sense of belonging, acceptance, and membership (Pallis 2004). The Bhutanese government emphasises the importance of cultural traditions and insists on national dress in government meetings and in school communities (Topping 2014). People communicate something to the outer world through the use of dress, clothes, and fashion (Ivanescu 2013).

Although clothing does not entirely define an individual, it plays a significant role in developing and maintaining one's spiritual and social identities (Pallis 2004). Clothing is a necessary part of one's body, and the body is recognised as the primary site of one's identity (Ivanescu 2013). Collective identities are expressed via cultural elements such as clothing, rituals, names, and customs. Collective identity defines the factors responsible for the similarities in people who occupy a particular category, while personal identity involves all those traits that make someone unique (Poletta and Jasper 2001). Collective identity emphasises the question "Who am I as a member of my group" rather than "who am I" (Usborne and Sablonniere 2014). This might be the reason why there was no significant difference in personal identity orientation between Kadazandusun participants who did and did not possess a traditional costume.

\section{Traditional Music and Identity Orientation}

Our study showed that Kadazandusun participants with the ability to play a traditional musical instrument tended to show a higher social identity orientation. From an attribution perspective, Epstein (1973) suggested that self-concept can be best viewed as a theory that people hold about themselves as an experiencing, functioning being interacting with the world. Music can be a powerful means of representing identity and asserting cultural differences (Block and Buckingham 2007). Some people shape their identities around music (Allet 2012), and music is significant in many people's lives, providing a source of pleasure, escapism, and identity. According to Lambson (2012), the instrument one plays is not only associated with our identity, it also defines one's identity. Nethsinghe (2012) stated that students are able to develop "a sense of musical and cultural selfidentity" through an understanding of their own musical backgrounds. Learning how to play a musical instrument may enhance one's understanding of the music that represents their own ethnic origin.

For Kadazandusun indigenous group, music plays an important role in their social events, including weddings, religious ceremonies and funeral. The Kadazandusun participants who were able to play a musical instrument showed higher scores for social identity than those who did not play an instrument. When playing music, participants might feel a sense of attachment to the traditional musical instrument that represents their ethnicity. We believe that when participants play a traditional musical instrument such as a gong, it might increase their interest in learning how to play other musical instruments, such as the kulintangan, gong, sompoton, and turali. Many researchers believe that music 
plays a significant role in strengthening social bonds, and playing music can make people feel connected with others (Suttie 2015).

Playing music in a group involves cooperation which increases one's trust (Suttie 2015). This is because traditional music is always played in a group, not individually, and this increases the opportunities to socialise and connect with people within the community. For instance, Kulintangan which is made up of six to nine brass kettle gongs arranged horizontally on a low wooden frame, is usually played together with other musical instruments, such as gong and gandang. The little gongs (kulintangan) have different pitches, and can produce fast tunes when hit by two wooden mallets (Carrybeans 2018). A set of gongs of different pitches is usually played together in social events, such as weddings, cultural festivals and religious ceremonies. Another type of Kadazandusun musical instrument is the sompoton, which made from a dried gourd and eight bamboo pipes arranged in a double layered raft and sealed using beeswax. The sompoton works similarly to a bagpipe (Carrybeans 2018). Some traditional music instruments can also be played individually, like the turali (noseflute), which is played as a solo form of personal expression in non-ritual contexts among most of the ancient indigenous Kadazandusun ethnic groups of Sabah (Pugh-Kitingan 2017). For the Kadazandusun, musical instruments is become part in their social and cultural lives.

The music people create conveys significant information about who they are, or at least who they think they are (Maybury-Lewis 1996). In central Brazil, the Suyá Indians are emphatic about music's central role in their culture; their singing defines them and their place in the world. In the Philippines, traditional music is used for creative expressions, addressing their artistic, ritual, economic, political, and social subjectivities, experiences and needs. Traditional music is also being used in the Philippines as a creative way to engage indigenous youth in a dialogue about self-identity (Daguitan 2014). Chinese people express their Chinese self even if the Chinese music includes non-native elements (Lam 2007). They believe music is essentially produced for, and consumed by, Chinese people; thus, an instrument can teach people something or mould them in a specific way.

Considering these findings from different communities, one can infer that music can be used as a means to formulate and to express individual identities. Different communities use different music styles of music in their rituals to reinforce their identities. For instance, music is an essential component among the Kichwa people in the Ecuadorian province of Napo for strengthening individual identities (Tacuri 2010). In Wagner's study (2015) on Irish communities, he found that music was part of Irish cultural identity. One of his participants stated that traditional music may help to express part of his cultural identity. For the Kadazandusuns, traditional music instruments, such as the gong, are not only for social entertainment but are also valuable family heirloom. They will give away gongs as part of a dowry, sogit (a fine), and play it during ceremonies (Carrybeans 2018). This shows that traditional musical instruments are perceived as cultural items that play important roles in Kadazandusun customs and social events. 


\section{Conclusions and Implications}

Our study revealed that people's identity orientation may differ based on cultural elements (e.g. possession of a Kadazandusun traditional costume and ability to play a traditional musical instrument). The research findings may provide an understanding of these two cultural elements to identity orientation, particularly for indigenous Kadazandusuns. It is our hope that the Kadazandusun Cultural Association and each Kadazandusun sub-ethnicity association will place more efforts into creating awareness regarding the critical value of Kadazandusun traditional costumes and music on Kadazandusuns' identity orientation. This can be achieved by implementing more cultural programmes to highlight the beauty and the symbolic meaning of the Kadazandusun costume accessories, and not only during significant events such as the Harvest Festival. Furthermore, providing more traditional music classes or music camps will give the Kadazandusun community opportunities to learn the skills necessary for playing traditional musical instruments. For instance, non-governmental organisations (NGOs), such as the Partner of Community Organisations (PACOS), has organised traditional music camps to encourage youths in the interior to play traditional musical instruments, as well as to perform traditional dances (Regis and Lasimbang n.d.).

The continuous efforts from all parties may create awareness, particularly among the younger Kadazandusun generation, to preserve the values of the Kadazandusun traditional costume and traditional musical instruments. Many young Kadazandusuns have lost interests in learning their old musical instruments. Traditional musical instruments are slowly losing their place in favour of modern instruments (Chong 2015). Efforts to keep the tradition alive have not gone unnoticed. The traditional costume and traditional musical instrument must be conserved for continuing the Kadazandusun culture and for the new generation to accept the uniqueness of their cultures. We hope this research study's findings may contribute to Kadazandusun literature and spark interests among the Kadazandusun association and future researchers to examine other cultural elements, such as language, traditional dance, and customs that may also reflect the Kadazandusun orientation identity.

It is our hope that more Kadazandusuns will show their appreciation for their traditional costume and music instrument as part of their culture and heritage. Suan (2015) stated that although Kadazandusun music culture has quickly been modernised, the older generation hopes their wisdom will continue to serve their people and that the bad influences from the outside world will not destroy future generations. For future studies, it would be interesting if we could extend our findings to other ethnicities in Sabah, such as Murut, Rungus, and Bajau for a comparison across different ethnic communities.

\section{Acknowledgement}

We would like to express our thanks to University Malaysia Sabah for the research grant (GKP0017-SS-2016). Special thanks to the enumerators and to all 
participants of Kadazandusuns who participated in this study.

\section{References}

Allet N (2012) As soon as that track starts, I feel...'unraveling attachments to extreme metal music with music elicitation. Innovations in Youth research: 21-36.

Anthony S (1996) Traditional music in community life. Languages and culture. Retrieved from https://bit.ly/2MRl08p.

Assman S (2008) Between tradition and innovation: The reinvention of the Kimono in Japanese Consumer Culture. The Journal of Dress, Body and Culture 12(3): 359-376.

Block LD, Buckingham D (2007) Rapping all over the world, music media and intercultural communication. Global Children, Global Media, 177-194

Carrausse S (2012) Dance, youth and changing gender identities in Korea. In H Neveu Kringelbach, J Skinner (Eds) Dancing cultures: Globalization, tourism, and identity in the anthropology of Dance, 177-193.New York: Berghahn Books.

Carryberry, SP (6 January, 2018). Sabahan Music 101: Traditional Musical Instruments. Retrieved from https://bit.ly/2O3kFUQ.

Cheek JM, Briggs SR (2013) Aspects of Identity Questionnaire (AIQ-IV). Measurement Instrument Database for the Social Science. Retrieved from https://bit.ly/2zLgXr3.

Chong LS (2015) Why the ancient musical essence is still retained in Dusun Tindal's instrumenatl music within its modern community? Paper presented at $3^{\text {rd }}$ Global conference on Business and Social Science.

Daguitan JC (August 18, 2014) Lessons in traditional music revitalize indigenous selfidentity. United Nations Radio.

Dayu S (2014) Persamaan dan perbezaan sebutan dan makna dalam pelbagai dialek bahasa Kadazandusun [Similarity and differences in terms and meanings in various dialects of Kadazandusun language]. Procedia - Social and Behavioral Sciences 134, $446-453$

Doksil M (May 30, 2015) Harvest pageant to showcase five new traditional costume. Retrieved from https://bit.ly/2xH0MZs.

Doksil M (June 05, 2016) Kaamatan best platform to showcase cultural diversity of Sabah's traditional costumes. Retrieved from https://bit.ly/2OHIfUu.

Epstein S (1973) The self-concept revisited or a theory of a theory. Am. Psychol. 28: 40416.

Hargreaves DJ, Miell D, MacDonald RA (2002) What are musical identities and why are they important? In DJ Hargreaves, D Miell, RAMacDonald (Eds) Musical Identities, 1-20. New York: Oxford University Press

Ivanescu C (2013) At home in my body: Sartorial practices of young Pakistani women in the Netherlands. Interraccoes 23: 30-55.

Kadazan Encyclopedia.com (2009) Worldmark Encyclopedia of Cultures and Daily Life. Cengage Learning.

Lambson L (2012) Musical identity: Defining instruments personalities. Retrieved from https://bit.ly/2NuaER5.

Lam J (2007) Music, globalization and the Chinese self. The Macalester International Roundtable, Institute for Global Citizenship, University of Michigan.

Lee MM (2015) Body, dress and identity in ancient Greece. NY: Cambridge University Press.

Luping HJ (2009) Indigenous Ethnic Communities of Sabah: The Kadazandusun.Kuala Lumpur: Ministry of Information, Communications and Culture Malaysia.

Maybury-Lewis D (December, 1996) Traditional music in community life, Cultural 
Survival Quarterly Magazine. Retrieved from https://bit.ly/2NyuUtB.

Matsumoto D (2000) Culture and psychology: People around the world, $2^{\text {nd }}$ ed.US: Wadsworth.

Mohd Said S (2018, June 20) Kaamatan boosts demand for traditional costumes. Utusan Borneo. Retrieved from https://bit.ly/2NYrya4.

Nethsinghe R (2012) Finding balance in a mix of culture: Appreciation of diversity through multicultural music education. International Journal of Music Education 30: 382-396. doi:10.1177/0255761412459166.

Oyserman D, Elmore K, Smith G (2012) Self, self-concept, and identity. In MR Leary, JP Tangney (eds), Handbook of Self and Identity, 69-104. NY: The Guilford Press.

Pallis M (2004) Do clothes make the person? The significance of human attire. In Y Progler (ed) Radical Essential Pamphlet Series Citizen International. Retrieved from https://bit.ly/2ppeX1A.

Polletta F, Jasper JM (2001) Collective identity and social movements. Annual Review Sociology 27:283-305

Pohl W (1998) Telling the Difference: Signs of ethnic identity. In P Walter, R Helmut (eds), Strategies of Distinction. The Construction of Ethnic Communities, 300-800 (Leiden), 17-69.

Pugh-Kitingan J (2017) Sources, sounds and meanings of turali (noseflute) music in Dusunic cultures of Sabah. Malaysian Music Journal 6(2): 1-28.

Regis P, Lasimbang R (n.d.) Introduction to Integration of Indigenous Culture into NonFormal Education Programmes in Sabah. Retrieved from https://bit.ly/2MSmEH0.

Roach-Higgins ME, Eicher JB (1992) Dress and identity. Clothing \& Textiles Research Journal 10(4): 1-8.

Sedikides C, Gaertner L, O’Mara M (2011) Individual Self, Relational Self, Collective Self: Hierarchical Ordering of the Tripartite Self. Psychol Study 56(1): 98-107. doi 10.1007/s12646-011-0059-0.

Suan CL (2015) Why the ancient musical essence is still retained in Dusun Tindal's instrumenatl music within its modern community? Paper presented at $3^{\text {rd }}$ Global conference on Business and Social Science.

Suttie J (March, 2015) Why we love music. Greater Good Magazine.

Tacuri MF (2010) Reinventing rituals and the role of music in the process of affirming identity among the Amazonian Kichwa-Quijos from Napo, Equador. Department of Anthropology University of Lethbridge, Alberta, Canada.

Tajfel (1981) Human Groups and Social Categories: Studies in Social Psychology. Cambridge: Cambridge University Press.

Topping A (2014, August 26) Bhutan battles to preserve its culture as development accelerates. The Guardian. Retrieved from https://bit.ly/2y6Pxd7.

Usborne E, Sablonniere R (2014) Understanding my culture means understanding myself: The function of cultural identity clarity for personal identity clarity and personal psychological well-being. Journal for the Theory of Social Behavior 44(4): 436-458

Wagner I (2015) Producing Excellence: The Making of Virtuosos. New Brunswick: Rutgers University Press. 